\title{
41. ORGANIC GEOCHEMISTRY OF SEDIMENTS FROM LEG 135 (LAU BASIN) AND OF AN OIL SEEP (TONGA)'
}

\author{
Martin G. Fowler ${ }^{2}$
}

\begin{abstract}
The average total organic carbon (TOC) content obtained after Rock-Eval/TOC analysis of 156 sediment samples from the eight sites cored during Leg 135 is $0.05 \%$. Hence, the TOC content of Leg 135 sediments is extremely low. The organic matter that is present in these samples is probably mostly reworked and oxidized material. Ten sediment samples were selected for extraction and analysis by gas chromatography and gas chromatography-mass spectrometry. Very low amounts of extractable hydrocarbons were obtained and some aspects of the biomarker distributions suggest that these hydrocarbons are not representative of the organic matter indigenous to the samples.

A sample of an oil seep from Pili, Tongatapu was also analyzed. The seep is a biodegraded, mature oil that shows many characteristics in common with previously published analyses of oil seeps from Tongatapu. Biomarker evidence indicates that it: source is a mature, marine carbonate of probable Late Cretaceous-Early Tertiary age. The source rock responsible for the Tongatapu oil seeps remains unknown.
\end{abstract}

\section{INTRODUCTION}

Previous work on the petroleum geochemistry of Tonga and the surrounding area was initiated because of the occurrence of oil seeps on Tongatapu. These were found in shallow holes at several locations in vuggy coral limestone of Pleistocene to Holocene age (Maung et al., 1981; Sandstrom and Philp, 1984; Sandstrom, 1985). Detailed geochemical analyses of five oil seeps from two different locations indicated that they were moderately to severely biodegraded, mature crude oils that probably had the same source (Sandstrom and Philp, 1984; Sandstrom, 1985). However, the suspicion that the oil seeps could be anthropogenic pollutants was not completely ruled out by these authors.

Attempts to identify possible source rocks for these seeps have been unsuccessful. Buchbinder and Halley (1985) reported the total organic carbon (TOC) contents of eight samples collected from outcrop and boreholes on Tongatapu and 'Eua. The best of these samples had a TOC content of $0.42 \%$ whereas the rest were below $0.25 \%$. When the sample with the highest TOC content was analyzed by Rock-Eval, it produced no $S_{2}$ peak indicating that it had no hydrocarbon potential. Sandstrom (1985) reported the TOC contents of eight dredge samples recovered during a cruise of the southern Tonga Platform by the S.P. Lee. The highest TOC content of these samples was $0.04 \%$. Microscopic observations of kerogen isolates indicated that most of the organic matter was terrestrially derived.

This paper presents the results obtained from organic geochemical analyses of sediment samples cored during Ocean Drilling Program (ODP) Leg 135 from the western Lau Basin, Tonga Ridge, and Tonga Forearc (Fig. 1), and of an oil seep from Tongatapu.

\section{EXPERIMENTAL METHODS}

An aliquot of each Leg 135 sample received was dried and powdered for Rock-Eval/TOC analysis. The instrument used was a Delsi Rock-Eval II pyrolysis unit equipped with a total organic carbon (TOC) analysis module. This instrument permits rapid determination of the amount, type, and maturity of organic matter in rock samples of about $100 \mathrm{mg}$. Briefly, this pyrolysis technique involves a microprocessor-controlled temperature program that causes the release of

\footnotetext{
'Hawkins, J.. Parson. L., Allan, J.. et al., 1994. Proc. ODP, Sci. Resuits, 135: College Station. TX (Ocean Drilling Program).

${ }^{2}$ Geological Survey of Canada, 3303 - 33rd Street NW, Calgary, Alberta T2L 2A7, Canada.
}

hydrocarbons and $\mathrm{CO}_{2}$ in a stream of helium. The amount of hydrocarbons is determined by a flame ionization detector (FID), whereas for $\mathrm{CO}_{2}$ a thermal conductivity detector (TCD) is employed. Table 1 contains the standard measured Rock-Eval parameters (Espitalié et al., 1977, 1985) as well as several derived parameters:

$\mathrm{TOC}=$ total organic carbon reported as the weight percent of the whole rock;

$\mathrm{S}_{1}=$ hydrocarbon evolved (distilled or thermovaporized) at $300^{\circ} \mathrm{C}$ ( $\mathrm{mg}$ hydrocarbon/g rock);

$\mathrm{S}_{2}=$ hydrocarbon evolved during heating at $25^{\circ} \mathrm{C} / \mathrm{min}$ between $300^{\circ} \mathrm{C}$ and $600^{\circ} \mathrm{C}$ ( $\mathrm{mg}$ hydrocarbon/g rock);

$\mathrm{S}_{3}=$ organic carbon dioxide evolved at $300^{\circ} \mathrm{C}$ and up to $390^{\circ} \mathrm{C}(\mathrm{mg}$ $\mathrm{CO}_{2} / \mathrm{g}$ rock);

$\mathrm{PI}=\mathrm{S}_{1} /\left(\mathrm{S}_{1}+\mathrm{S}_{2}\right)$

$\mathrm{T}_{\max }=$ the temperature $\left({ }^{\circ} \mathrm{C}\right)$ at the top of the $\mathrm{S}_{2}$ peak;

$\mathrm{HI}=$ hydrogen index, which is $\left(100 \times \mathrm{S}_{2}\right) / \mathrm{TOC}(\mathrm{mg} \mathrm{HC} / \mathrm{g}$ TOC$)$; and

$\mathrm{OI}=$ oxygen index, which is $\left(100 \times \mathrm{S}_{3}\right) / \mathrm{TOC}\left(\mathrm{mg} \mathrm{CO}_{2} / \mathrm{g} \mathrm{TOC}\right)$.

Ten samples were selected for more detailed geochemical analysis based on the Rock-Eval/TOC results and, because of the low TOC contents of the samples, on the quantity of sample available. Hence, there was a tendency to choose samples from shallow depths from which pore waters had been squeezed as these were the largest samples available. The samples were pulverized and then extracted for $24 \mathrm{hr}$ in Soxhlet apparatus using azeotropic chloroform:methanol (87:13). These extracts and the oil seep sample were deasphalted using n-pentane before fractionation. The deasphalted fractions were fractionated using open-column chromatography (three-fourths activated alumina and one-fourth activated silica gel with an adsorbent:sample mass ratio of 100:1). Saturates were recovered by eluting with $3.5 \mathrm{~mL}$ of pentane $/ \mathrm{g}$ of adsorbent. Aromatics were recovered by eluting with $4.0 \mathrm{~mL}$ of 50:50 pentane-dichloromethane/g of absorbent, and the resins were recovered with $4.0 \mathrm{~mL} / \mathrm{g}$ methanol.

The oil seep gasoline-range hydrocarbons were analyzed using an OI Corporation 4660A Purge and Trap connected to a HewlettPackard 5890A Gas Chromatograph fitted with a 50-m, 0.31-i.d. DB-1 fused silica column.

Gas chromatograms of the saturate fractions were acquired on a Varian 3700 FID gas chromatograph (GC) using a 30-m DB- 1 column with a temperature program of $60^{\circ}-300^{\circ} \mathrm{C}$ at $6^{\circ} \mathrm{C} / \mathrm{min}$. Gas chromatography-mass spectrometry (GC-MS) data were collected using a VG 70 SQ hybrid MS-MS (100 $\mu \mathrm{A}$ trap current and $70 \mathrm{eV}$ ionization 
Table 1. Results of Rock-Eval/TOC analyses of Leg 135 cored sediment samples.

\begin{tabular}{|c|c|c|c|c|c|c|c|c|c|}
\hline $\begin{array}{l}\text { Core. section, } \\
\text { interval }(\mathrm{cm})\end{array}$ & $\begin{array}{l}\text { Depth } \\
\text { (mbsf) }\end{array}$ & TOC & $s_{1}$ & $\mathrm{~S}_{2}$ & $\mathrm{~S}_{3}$ & PI & $\mathrm{T}_{\operatorname{mix}}$ & $\mathrm{HI}$ & OI \\
\hline \multicolumn{10}{|l|}{$135-834 \mathrm{~A}-$} \\
\hline IH-3. 102-103 & 4.02 & 0.02 & 0.06 & 0.03 & 3.70 & 0.67 & 0 & 150 & 18500 \\
\hline $\mathrm{IH}-4,140-150$ & 5.90 & 0.02 & 0.02 & 0.07 & 1.53 & 0.22 & 365 & 350 & 7650 \\
\hline $2 \mathrm{H}-3,75-76$ & 11.35 & 0.01 & 0.03 & 0.02 & 2.46 & 0.60 & 379 & 200 & 24600 \\
\hline $2 \mathrm{H}-4,140-150$ & 13.50 & 0.02 & 0 & 0.01 & 2.06 & 0 & 0 & 50 & 10300 \\
\hline $3 \mathrm{H}-2,60-6 \mathrm{I}$ & 19.20 & 0.01 & 0.02 & 0.01 & 2.64 & 1 & 445 & 100 & 26400 \\
\hline $3 \mathrm{H}-4.140-150$ & 23.00 & 0.01 & 0 & 0.01 & 2.29 & 0 & 0 & 100 & 22900 \\
\hline $4 \mathrm{H}-4.73-74$ & 31.83 & 0.08 & 0.02 & 0.70 & 2.37 & 0.03 & 443 & 875 & 2963 \\
\hline $4 \mathrm{H}-4,140-150$ & 32.50 & 0.02 & 0 & 0.01 & 2.14 & 0 & 0 & 50 & 10700 \\
\hline $5 \mathrm{H}-4,73-74$ & 41.33 & 0.07 & 0 & 0.01 & 2.73 & 0 & 0 & 14 & 3900 \\
\hline $5 \mathrm{H}-4,140-150$ & 42.00 & 0.03 & 0 & 0.01 & 2.95 & 0 & 0 & 33 & 9833 \\
\hline $6 \mathrm{H}-2.75-76$ & 47.85 & 0.03 & 0 & 0.01 & 2.47 & 0 & () & 33 & 8233 \\
\hline $6 \mathrm{H}-4.140-150$ & 51.50 & 0.01 & 0 & 0.01 & 2.09 & 0 & 0 & 100 & 20900 \\
\hline $7 \mathrm{H}-6,81-82$ & 63.41 & 0.02 & 0 & 0.01 & 1.37 & 0 & 0 & 50 & 6850 \\
\hline $8 \mathrm{H}-1.96-97$ & 65.56 & 0.46 & 0.01 & 0.02 & 2.99 & 0.33 & 0 & 4 & 650 \\
\hline $9 \mathrm{H}-2,109-11 \mathrm{I}$ & 76.69 & 0.08 & 0 & 0.01 & 2.79 & 0 & 0 & 13 & 3488 \\
\hline $9 \mathrm{H}-4.140-150$ & 80.00 & 0.03 & 0.01 & 0.03 & 4.36 & 0.25 & 449 & 100 & 14533 \\
\hline $10 X-1.81-82$ & 84.41 & 0.09 & 0.02 & 0.01 & 2.59 & 0.67 & 0 & 11 & 2878 \\
\hline $11 X-1,79-80$ & 93.99 & 0.03 & 0.12 & 0.11 & 2.83 & 0.52 & 382 & 367 & 9433 \\
\hline $12 \mathrm{X}-1,140-150$ & 104.30 & 0.04 & 0 & 0.01 & 2.08 & 0 & 0 & 25 & 5200 \\
\hline $12 X-2,53-54$ & 104.93 & 0.07 & 0 & 0.01 & 2.78 & 0 & 0 & 14 & 3971 \\
\hline $16 \mathrm{X}-1.140-150$ & 133.30 & 0.01 & 0 & 0.01 & 0.07 & 0 & 0 & 100 & 700 \\
\hline \multicolumn{10}{|l|}{$135-835 \mathrm{~A}-$} \\
\hline IH-4. $140-150$ & 5.90 & 0.04 & 0 & 0.01 & 3.21 & 0 & 0 & 25 & 8025 \\
\hline $1 \mathrm{H}-5,30-31$ & 6.30 & 0.03 & 0.07 & 0.05 & 2,86 & 0.58 & 310 & 167 & 9533 \\
\hline $2 \mathrm{H}-2,69-70$ & 11.69 & 0.04 & 0.01 & 0 & 2.82 & 1.00 & 0 & 0 & 7050 \\
\hline $2 \mathrm{H}-4,50-51$ & 14.50 & 0.05 & 0.03 & 0 & 3.38 & 1.00 & 0 & 0 & 6760 \\
\hline $2 \mathrm{H}-4,140-150$ & 15.40 & 0.02 & 0 & 0.01 & 1.97 & 0 & 0 & 50 & 9850 \\
\hline $2 \mathrm{H}-5,27-34$ & 15.77 & 0.05 & 0 & 0.01 & 3.13 & 0 & 0 & 20 & 6260 \\
\hline $3 \mathrm{H}-4,140-150$ & 24.90 & 0.02 & 0 & 0.01 & 2.21 & 0 & 0 & 50 & 11050 \\
\hline $4 \mathrm{H}-2,73-74$ & 30.73 & 0.03 & 0 & 0.01 & 2.19 & 0 & 0 & 33 & 7300 \\
\hline $4 \mathrm{H}-4,140-150$ & 34.40 & 0.01 & 0 & 0.01 & 1.97 & 0 & 0 & 100 & 19700 \\
\hline $5 \mathrm{H}-2,104-105$ & 40.54 & 0.04 & 0.05 & 0.03 & 2.61 & 0.63 & 302 & 75 & 6525 \\
\hline $6 \mathrm{H}-2,71-72$ & 49.71 & 0.05 & 0.01 & 0.02 & 2.74 & 0.33 & 365 & 40 & 5480 \\
\hline $6 \mathrm{H}-4,140-150$ & 53.40 & 0.01 & 0 & 0.01 & 1.73 & 0 & 0 & 100 & 17300 \\
\hline $6 \mathrm{H}-7,19-20$ & 56.69 & 0.06 & 0.02 & 0.01 & 3.14 & 0.67 & 304 & 17 & 5233 \\
\hline $7 \mathrm{H}-2,93-94$ & 59.43 & 0.03 & 0.01 & 0 & 2.75 & 1.00 & 0 & 0 & 9167 \\
\hline $7 \mathrm{H}-7.54-55$ & 66.54 & 0.10 & 0.01 & 0.01 & 3.13 & 0.50 & 337 & 10 & 3130 \\
\hline $8 \mathrm{H}-2,72-73$ & 68.72 & 0.03 & 0.01 & 0 & 2.88 & 1.00 & 0 & 0 & 9600 \\
\hline $8 \mathrm{H}-4.140-150$ & 72.40 & 0.03 & 0 & 0.01 & 2.65 & 0 & 0 & 33 & 8833 \\
\hline $9 \mathrm{H}-2.78-79$ & 78.28 & 0.07 & 0.01 & 0 & 2.61 & 1.00 & 0 & 0 & 3729 \\
\hline $10 \mathrm{H}-2,66-67$ & 87.66 & 0.04 & 0.01 & 0.02 & 2.75 & 0.33 & 310 & 50 & 6875 \\
\hline $10 \mathrm{H}-4,67-68$ & 90.67 & 0.10 & 0.02 & 0.02 & 3.17 & 0.50 & 310 & 20 & 3170 \\
\hline $10 \mathrm{H}-4,140-150$ & 91.40 & 0.01 & 0 & 0.01 & 0.01 & 0 & 0 & 100 & 100 \\
\hline $1 \mathrm{IH}-6,70-71$ & 103.20 & 0.06 & 0.02 & 0.01 & 3.18 & 0.67 & 0 & 17 & 5300 \\
\hline $12 \mathrm{H}-2.69-70$ & 106.69 & 0.05 & 0.01 & 0 & 3.12 & 1.00 & 0 & 0 & 6240 \\
\hline $12 \mathrm{H}-4.140-150$ & 110.40 & 0.04 & 0 & 0.01 & 2.29 & 0 & 0 & 25 & 5725 \\
\hline $12 \mathrm{H}-6.69-70$ & 112.69 & 0.04 & 0.02 & 0 & 3.44 & 1.00 & 0 & 0 & 8600 \\
\hline $13 \mathrm{H}-6,91-92$ & 122.69 & 0.08 & 0.03 & 0.01 & 3.20 & 0.75 & 407 & 13 & 4000 \\
\hline $14 \mathrm{H}-4,92-99$ & 128.92 & 0.04 & 0 & 0.01 & 2.68 & 0 & 0 & 25 & 6700 \\
\hline $14 \mathrm{H}-4,140-150$ & 129.40 & 0.04 & 0 & 0.01 & 2.63 & 0 & 0 & 25 & 6575 \\
\hline $14 \mathrm{H}-6.47-48$ & 131.47 & 0.04 & 0.03 & 0 & 3.86 & 1.00 & 0 & 0 & 9650 \\
\hline $15 \mathrm{H}-3.61-62$ & 136.23 & 0.09 & 0.02 & 0 & 3.72 & 1.00 & 0 & 0 & 4133 \\
\hline $16 \mathrm{H}-2,69-71$ & 144.69 & 0.17 & 0.07 & 0 & 3.94 & 1.00 & 0 & 0 & 2318 \\
\hline $16 \mathrm{H}-6,140-150$ & 151.35 & 0.06 & 0 & 0.01 & 2,43 & 0 & 0 & 17 & 4050 \\
\hline $17 \mathrm{H}-1.74-75$ & 152.74 & 0.05 & 0.01 & 0 & 2.79 & 1.00 & 0 & 0 & 5580 \\
\hline \multicolumn{10}{|l|}{$135-836 \mathrm{~A}-$} \\
\hline $1 \mathrm{H}-1.57-58$ & 0.57 & 0.02 & 0.07 & 0.09 & 2.60 & 0.44 & 367 & 450 & 13000 \\
\hline $2 \mathrm{H}-1,62-63$ & 1.82 & 0.04 & 0.20 & 0.19 & 2.13 & 0.51 & 369 & 475 & 5325 \\
\hline $2 \mathrm{H}-3,63-64$ & 4.83 & 0.03 & 0.01 & 0.01 & 3.18 & 0.50 & 445 & 33 & 10600 \\
\hline $2 \mathrm{H}-4,140-150$ & 7.10 & 0.07 & 0 & 0.01 & 2.44 & 0 & 348 & 14 & 3486 \\
\hline $2 \mathrm{H}-6,71-72$ & 9.41 & 0.03 & 0.01 & 0.01 & 2.65 & 0.50 & 445 & 33 & 8833 \\
\hline $3 \mathrm{H}-5,20-2 \mathrm{I}$ & 16.78 & 0.01 & 0.03 & 0.02 & 2.39 & 0.60 & 427 & 200 & 23900 \\
\hline $3 \mathrm{H}-5,140-150$ & 17.98 & 0.02 & 0 & 0.01 & 1.88 & 0 & 412 & 50 & 9400 \\
\hline $3 \mathrm{H}-6,69-70$ & 18.77 & 0.03 & 0.06 & 0.08 & 2.69 & 0.43 & 459 & 267 & 8967 \\
\hline \multicolumn{10}{|l|}{$135-837 \mathrm{~A}-$} \\
\hline $\mathrm{IH}-3,69-70$ & 3.69 & 0.03 & 0.11 & 0.16 & 2.39 & 0.41 & 365 & 533 & 7967 \\
\hline $1 \mathrm{H}-3,140-150$ & 4.40 & 0.04 & 0 & 0.01 & 2.78 & 0 & 0 & 25 & 6950 \\
\hline IH-4. 78-79 & 5.28 & 0.01 & 0 & 0.01 & 0.01 & 0 & 343 & 100 & 100 \\
\hline $2 \mathrm{H}-4,140-150$ & 13.90 & 0.03 & 0 & 0.01 & 2.55 & 0 & 0 & 33 & 8500 \\
\hline $3 \mathrm{H}-4,140-150$ & 23.40 & 0.02 & 0 & 0.01 & 2.76 & 0 & 0 & 50 & 13800 \\
\hline $4 \mathrm{H}-4,140-150$ & 32.90 & 0.02 & 0.02 & 0.32 & 0.23 & 0.06 & 0 & 1600 & 1150 \\
\hline $4 \mathrm{H}-5,81-82$ & 33.72 & 0.01 & 0.02 & 0.03 & 2.76 & 0.40 & 370 & 300 & 27600 \\
\hline $6 \mathrm{H}-5,140-150$ & 53.40 & 0.06 & 0 & 0.02 & 3.26 & 0 & 373 & 33 & 5433 \\
\hline
\end{tabular}


Table 1 (continued).

\begin{tabular}{|c|c|c|c|c|c|c|c|c|c|}
\hline $\begin{array}{l}\text { Core, section, } \\
\text { interval }(\mathrm{cm})\end{array}$ & $\begin{array}{l}\text { Depth } \\
\text { (mbsf) }\end{array}$ & TOC & $\mathrm{S}_{1}$ & $\mathrm{~S}_{2}$ & $\mathrm{~S}_{3}$ & PI & $\mathrm{T}_{\text {max }}$ & $\mathrm{HI}$ & OI \\
\hline \multicolumn{10}{|l|}{$135-837 \mathrm{~A}-$} \\
\hline $8 \mathrm{H}-2,86-87$ & 67.36 & 0.04 & 0.14 & 0.14 & 3.26 & 0.50 & 372 & 350 & 8150 \\
\hline $8 \mathrm{H}-4,140-150$ & 70.90 & 0.05 & 0.01 & 0.01 & 2.90 & 0.50 & 310 & 20 & 5800 \\
\hline $9 \mathrm{H}-4,63-64$ & 79.63 & 0.05 & 0.04 & 0.04 & 3.31 & 0.50 & 449 & 80 & 6620 \\
\hline \multicolumn{10}{|l|}{$135-838 \mathrm{~A}-$} \\
\hline $2 \mathrm{H}-4.140-150$ & 9.60 & 0.02 & 0 & 0.01 & 2.82 & 0 & 353 & 50 & 14100 \\
\hline $3 \mathrm{H}-4,140-150$ & 19.10 & 0.01 & 0 & 0.01 & 2.27 & 0 & 0 & 100 & 22700 \\
\hline $4 \mathrm{H}-4,140-150$ & 28.60 & 0.03 & 0.01 & 0.04 & 3.27 & 0.20 & 388 & 133 & 10900 \\
\hline $8 \mathrm{H}-4,140-150$ & 66.60 & 0.02 & 0 & 0.04 & 2.32 & 0 & 401 & 200 & 11600 \\
\hline \multicolumn{10}{|l|}{$135-839 \mathrm{~A}-$} \\
\hline $1 \mathrm{H}-2,140-150$ & 2.90 & 0.01 & 0 & 0.04 & 1.42 & 0 & 431 & 400 & 14200 \\
\hline IH-3, 69-70 & 3.69 & 0.03 & 0 & 0.01 & 3.54 & 0 & 0 & 33 & 11800 \\
\hline $2 \mathrm{H}-4.140-150$ & 10.40 & 0.02 & 0 & 0.01 & 2.52 & 0 & 530 & 50 & 12600 \\
\hline $3 \mathrm{H}-4.140-150$ & 19.90 & 0.03 & 0.04 & 0.37 & 0.31 & 0.10 & 0 & 1233 & 1033 \\
\hline $6 \mathrm{H}-4,140-150$ & 48.40 & 0.01 & 0.04 & 0.19 & 0.58 & 0.17 & 0 & 1900 & 5800 \\
\hline $8 \mathrm{H}-4,140-150$ & 67.40 & 0.02 & 0.03 & 0.23 & 0.46 & 0.12 & 0 & 1150 & 2300 \\
\hline $4 \mathrm{H}-5.140-150$ & 30.90 & 0.02 & 0 & 0.01 & 2.18 & 0 & 0 & 50 & 10900 \\
\hline $10 \mathrm{H}-5.140-150$ & 87.90 & 0.05 & 0.03 & 0.06 & 2.66 & 0.33 & 310 & 120 & 5320 \\
\hline \multicolumn{10}{|l|}{ 135-840A- } \\
\hline IH-3, 55-56 & 3.60 & 0.01 & 0.05 & 0.06 & 0.56 & 0.45 & 339 & 600 & 5600 \\
\hline \multicolumn{10}{|l|}{ I35-840B- } \\
\hline $1 X-1,13-14$ & 0.13 & 0.05 & 0.14 & 0.18 & 1.31 & 0.44 & 390 & 360 & 2620 \\
\hline $4 X-C C, 12-13$ & 28.52 & 0.01 & 0.06 & 0.05 & 0.76 & 0.55 & 310 & 500 & 7600 \\
\hline $9 \mathrm{X}-\mathrm{CC}, 4-5$ & 76.44 & 0.03 & 0.13 & 0.10 & 0.72 & 0.57 & 376 & 333 & 2400 \\
\hline $10 X-1,12-13$ & 86.22 & 0.02 & 0.08 & 0.07 & 0.71 & 0.53 & 310 & 350 & 3550 \\
\hline $11 X-2,70-71$ & 97.90 & 0.02 & 0.15 & 0.09 & 0.71 & 0.63 & 348 & 450 & 3550 \\
\hline $12 X-4,104-105$ & 109.52 & 0.02 & 0.06 & 0.01 & 0.91 & 0.86 & 310 & 50 & 4550 \\
\hline $12 X-4,140-150$ & 109.88 & 0.01 & 0.01 & 0 & 1.12 & 1.00 & 0 & 0 & 11200 \\
\hline $13 X-2,140-150$ & 118.00 & 0.01 & 0 & 0.01 & 1.21 & 0 & 0 & 100 & 12100 \\
\hline $15 \mathrm{X}-\mathrm{CC}, 0-1$ & 134.40 & 0.05 & 0.19 & 0.17 & 0.76 & 0.53 & 413 & 340 & 1520 \\
\hline $22 \mathrm{X}-\mathrm{CC}, 7-8$ & 201.77 & 0.06 & 0.21 & 0.12 & 1.03 & 0.64 & 394 & 200 & 1717 \\
\hline $29 X-1,13-14$ & 269.53 & 0.14 & 0.28 & 0.18 & 1.19 & 0.61 & 378 & 129 & 850 \\
\hline $31 X-1,44-45$ & 289.24 & 0.03 & 0.08 & 0.06 & 0.86 & 0.57 & 330 & 200 & 2867 \\
\hline $35 \mathrm{X}-1,18-19$ & 327.68 & 0.04 & 0.06 & 0.07 & 0.52 & 0.46 & 309 & 175 & 1300 \\
\hline $38 \mathrm{X}-1,124-125$ & 348.34 & 0.03 & 0.05 & 0.03 & 0.57 & 0.63 & 309 & 100 & 1900 \\
\hline $39 \mathrm{X}-1.18-23$ & 356.98 & 0.01 & 0 & 0.02 & 0.74 & 0 & 310 & 200 & 7400 \\
\hline $42 X-3,8-10$ & 388.88 & 0.03 & 0.02 & 0.02 & 0.59 & 0.50 & 309 & 66 & 1966 \\
\hline $49 X-1.68-69$ & 453.08 & 0.09 & 0.11 & 0.11 & 1.49 & 0.22 & 376 & 122 & 1656 \\
\hline $51 \times-5,44-45$ & 478.14 & 0.05 & 0.12 & 0.10 & 0.61 & 0.22 & 310 & 200 & 1220 \\
\hline $53 \times-4,59-60$ & 496.09 & 0.04 & 0.08 & 0.07 & 1.10 & 0.57 & 347 & 175 & 2750 \\
\hline $56 X-2,56-57$ & 522.22 & 0.07 & 0.12 & 0.09 & 1.27 & 0.57 & 421 & 129 & 1814 \\
\hline \multicolumn{10}{|l|}{$135-840 \mathrm{C}$} \\
\hline IH-2, $127-128$ & 40.77 & 0.01 & 0.07 & 0.05 & 0.74 & 0.58 & 349 & 500 & 7400 \\
\hline $3 \mathrm{H}-2,126-136$ & 59.76 & 0.01 & 0.01 & 0.03 & 0.42 & 0.25 & 392 & 300 & 4200 \\
\hline $4 \mathrm{H}-2,103-104$ & 69.03 & 0.03 & 0.05 & 0.06 & 0.56 & 0.45 & 357 & 200 & 1867 \\
\hline $4 \mathrm{H}-4,140-150$ & 72.40 & 0.01 & 0.01 & 0.01 & 0.74 & 0.50 & 310 & 100 & 7400 \\
\hline $5 \mathrm{H}-1,139-147$ & 125.39 & 0.07 & 0 & 0.03 & 0.47 & 0 & 341 & 43 & 671 \\
\hline $6 \mathrm{H}-4.52-53$ & 139.02 & 0.02 & 0.05 & 0.02 & 0.88 & 0.71 & 449 & 100 & 4400 \\
\hline $7 \mathrm{H}-2,143-150$ & 144.78 & 0.01 & 0 & 0.01 & 0.30 & 0 & 0 & 100 & 3000 \\
\hline $10 \mathrm{H}-1,52-53$ & 172,02 & 0.02 & 0.07 & 0.07 & 0.50 & 0.50 & 367 & 350 & 2500 \\
\hline \multicolumn{10}{|l|}{$135-841 \mathrm{~A}-$} \\
\hline IH-1, 88-89 & 0.88 & 0.13 & 0.19 & 1.05 & 0.22 & 0.15 & 0 & 808 & 169 \\
\hline $1 \mathrm{H}-4,140-150$ & 5.90 & 0.03 & 0.04 & 0.33 & 0.26 & 0.11 & 582 & 1100 & 867 \\
\hline IH- $-5,80-81$ & 6.80 & 0.14 & 0.25 & 1.01 & 0.21 & 0.20 & 0 & 721 & 150 \\
\hline $2 \mathrm{H}-4,15-16$ & 13.15 & 0.24 & 0.50 & 1.01 & 0.21 & 0.33 & 0 & 421 & 88 \\
\hline $2 \mathrm{H}-4,140-150$ & 14.40 & 0.08 & 0.17 & 0.48 & 0.07 & 0.26 & 475 & 600 & 88 \\
\hline $3 \mathrm{H}-3,82-83$ & 21.82 & 0.24 & 0.67 & 1.92 & 0.11 & 0.26 & 0 & 800 & 46 \\
\hline $3 \mathrm{H}-4,140-150$ & 23.90 & 0.18 & 0.48 & 1.75 & 0.01 & 0.22 & 498 & 972 & 6 \\
\hline $4 \mathrm{H}-3.76-77$ & 31.26 & 0.28 & 0.88 & 2.38 & 0.06 & 0.27 & 521 & 850 & 21 \\
\hline $4 \mathrm{H}-4,140-150$ & 33.40 & 0.06 & 0.26 & 0.58 & 0.01 & 0.31 & 530 & 967 & 17 \\
\hline $6 \mathrm{H}-2,9-10$ & 48.09 & 0.18 & 0.62 & 1.16 & 0.01 & 0.35 & 586 & 644 & 6 \\
\hline $6 \mathrm{H}-4,140-150$ & 52.40 & 0.08 & 0.12 & 0.96 & 0.01 & 0.11 & 506 & 1200 & 13 \\
\hline $8 \mathrm{H}-3,140-150$ & 69.90 & 0.02 & 0.04 & 0.20 & 0.21 & 0.17 & 0 & 1000 & 1050 \\
\hline $15 X-1,62-63$ & 130.22 & 0.11 & 0.20 & 0.33 & 0.54 & 0.38 & 532 & 300 & 491 \\
\hline $21 X-1,80-81$ & 177.70 & 0.12 & 0.16 & 0.41 & 0.36 & 0.28 & 551 & 342 & 300 \\
\hline \multicolumn{10}{|l|}{ |35-84|B- } \\
\hline $2 \mathrm{R}-1.47-48$ & 170.27 & 0.09 & 0.12 & 0.19 & 0.30 & 0.39 & 0 & 211 & 333 \\
\hline $2 R-1,142-150$ & 171.22 & 0.04 & 0.03 & 0.06 & 1.03 & 0.33 & 336 & 150 & 2575 \\
\hline $5 R-1,152-150$ & 200.12 & 0.06 & 0.03 & 0.07 & 0.61 & 0.30 & 331 & 117 & 1017 \\
\hline $8 \mathrm{R}-1.75-85$ & 228.45 & 0.02 & 0.02 & 0.03 & 0.43 & 0.40 & 395 & 150 & 2150 \\
\hline
\end{tabular}


Table 1 (continued).

\begin{tabular}{|c|c|c|c|c|c|c|c|c|c|}
\hline $\begin{array}{l}\text { Core, section, } \\
\text { interval }(\mathrm{cm})\end{array}$ & $\begin{array}{l}\text { Depth } \\
\text { (mbsf) }\end{array}$ & TOC & $S_{1}$ & $\mathrm{~S}_{2}$ & $\mathrm{~S}_{3}$ & PI & $\mathrm{T}_{\max }$ & $\mathrm{HI}$ & OI \\
\hline \multicolumn{10}{|l|}{ 135-84IB- } \\
\hline IIR-I.61-74 & 257.31 & 0.02 & 0.01 & 0.11 & 0.33 & 0.08 & 593 & 550 & 1650 \\
\hline $15 \mathrm{R}-1,135-150$ & 296.25 & 0.02 & 0 & 0.02 & 0.02 & 0 & 352 & 100 & 100 \\
\hline $18 R-2,77-95$ & 325.77 & 0.01 & 0.01 & 0.12 & 0.01 & 0.08 & 403 & 1200 & 100 \\
\hline $21 \mathrm{R}-1,12-32$ & 352.22 & 0.01 & 0 & 0.12 & 0.07 & 0 & 434 & 1200 & 700 \\
\hline $29 \mathrm{R}-1,130-150$ & 430.40 & 0.01 & 0 & 0.02 & 0.03 & 0 & 401 & 200 & 300 \\
\hline $32 \mathrm{R}-1,104-105$ & 459.14 & 0.08 & 0.07 & 0.08 & 0.56 & 0.47 & 371 & 100 & 700 \\
\hline $33 \mathrm{R}-1,8-9$ & 467.88 & 0.07 & 0.13 & 0.06 & 0.19 & 0.68 & 326 & 86 & 271 \\
\hline $35 \mathrm{R}-3,125-126$ & 491.39 & 0.03 & 0.04 & 0 & 0.15 & 1 & 0 & 0 & 500 \\
\hline $37 \mathrm{R}-3,0-13$ & 509.27 & 0.01 & 0 & 0.01 & 0.09 & 0 & 0 & 100 & 900 \\
\hline $40 \mathrm{R}-2,8-20$ & 536.81 & 0.01 & 0 & 0.05 & 0.10 & 0 & 367 & 500 & 1000 \\
\hline $40 R-3,35-36$ & 537.08 & 0.11 & 0.20 & 0.06 & 0.43 & 0.77 & 364 & 55 & 391 \\
\hline $42 \mathrm{R}-3,0-9$ & 557.30 & 0.01 & 0 & 0.01 & 0.58 & 0 & 0 & 100 & 5800 \\
\hline $45 \mathrm{R}-1.6-8$ & 583.36 & 0.01 & 0.11 & 0.04 & 0.77 & 0.73 & 400 & 400 & 7700 \\
\hline $46 \mathrm{R}-1,71-73$ & 593.61 & 0.06 & 0.06 & 0.07 & 0.64 & 0.46 & 363 & 117 & 1067 \\
\hline $46 \mathrm{R}-2,12-13$ & 594.52 & 0.08 & 0.05 & 0.06 & 0.61 & 0.45 & 349 & 75 & 763 \\
\hline $46 R-2,72-73$ & 595.12 & 0.05 & 0.03 & 0.01 & 0.39 & 0.75 & 310 & 20 & 780 \\
\hline $46 \mathrm{R}-2,111-112$ & 595,51 & 0.06 & 0 & 0.02 & 0.41 & 0 & 310 & 33 & 683 \\
\hline $46 \mathrm{R}-3,8-10$ & 595.94 & 0.06 & 0.05 & 0.05 & 0.42 & 0.50 & 349 & 83 & 700 \\
\hline $46 \mathrm{R}-\mathrm{CC}, 14-15$ & 596.37 & 0.10 & 0.10 & 0.16 & 0.68 & 0.38 & 400 & 160 & 680 \\
\hline $47 \mathrm{R}-1.143-144$ & 604.03 & 0.13 & 0.15 & 0.09 & 0.46 & 0.63 & 310 & 69 & 354 \\
\hline 51R-3, 0-19 & 642.80 & 0.03 & 0.07 & 0.41 & 0.01 & 0.15 & 490 & 1367 & 33 \\
\hline $53 \mathrm{R}-1.132-150$ & 661.92 & 0.01 & 0.02 & 0.18 & 0.01 & 0.10 & 380 & 1800 & 100 \\
\hline $54 R-3,65-66$ & 673.85 & 0.01 & 0.04 & 0.19 & 0.01 & 0.17 & 464 & 1900 & 100 \\
\hline $62 \mathrm{R}-1,130-150$ & 748.50 & 0.01 & 0 & 0.13 & 0.03 & 0 & 447 & 1300 & 300 \\
\hline
\end{tabular}

Notes: Derived parameters ( $\mathrm{T}_{\text {m.. }}$. HI. and $\mathrm{OI}$ ) are suspect because of the low TOC and high $\mathrm{CaCO}_{\text {, }}$ concentrations of the sediments. TOC $=$ total organic carbon as weight percent of the whole rock: $\mathrm{S}_{1}=$ hydrocarbon evolved (distilled or thermovaporitized) at $300^{\circ} \mathrm{C}\left(\mathrm{mg} \mathrm{HC} \mathrm{g}\right.$ rock): $\mathrm{S}_{2}=$ hydrocarbon evolved during heating at $25^{\circ} \mathrm{C} / \mathrm{min}$ between $300^{\circ}$ and $600^{\circ} \mathrm{C}(\mathrm{mg} \mathrm{HC} / \mathrm{g} \mathrm{rock}): \mathrm{S}_{3}=$ organic carbon dioxide evolved at $300^{\circ} \mathrm{C}$ and up to $390^{\circ} \mathrm{C}\left(\mathrm{mg} \mathrm{CO} / \mathrm{g}\right.$ rock): $\mathrm{PI}=\mathrm{S}_{1} /\left(\mathrm{S}_{1}+\mathrm{S}_{2}\right): \mathrm{T}_{\max }=$ temperature $\left({ }^{\circ} \mathrm{C}\right)$ at the top of the $\mathrm{S}$, peak: $\mathrm{HI}=$ hydrogen index $(100 \times \mathrm{S}$, $) / \mathrm{TOC}(\mathrm{mg} \mathrm{HC} / \mathrm{g} \mathrm{TOC})$; and $\mathrm{OI}=$ oxygen

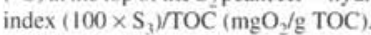

voltage) under the control of a VG 11-250 data system. The gas chromatograph was fitted with a $25-\mathrm{m} \mathrm{DB}-5$ column that was coupled directly to the ion source and temperature programmed from $50^{\circ}$ to $310^{\circ} \mathrm{C}$ at $4^{\circ} \mathrm{C} / \mathrm{min}$. The high-resolution, multiple ion detection (MID) experiments monitored the following ions: $\mathrm{m} / \mathrm{z}$ 177.1638, 191.1794, $217.1950,218.2028,231.2106$, and 259.2262 for the saturate fraction and $\mathrm{m} / \mathrm{z} 231.1170$ for the triaromatic steroids in the aromatic fraction. Full scan data, for peak identification by comparison of mass spectra, were obtained for the seep sample by scanning from $\mathrm{m} / \mathrm{z} 650$ to 50 at $1 \mathrm{~s} /$ decade. Sterane and hopane distributions in the oil seep sample were also examined using Collision Activated Decomposition MSMS as described by Fowler and Brooks (1990).

\section{ROCK-EVAL/TOC ANALYSES OF LEG 135 SAMPLES}

Organic carbon determinations given in the individual site chapters of the Leg 135 Initial Reports volume (Parson, Hawkins, Allan, et al., 1992) were obtained indirectly as the difference between total carbon and inorganic carbon values. The Rock-Eval instrument on the JOIDES Resolution was only operational for the last two sites drilled ( 840 and 841 ) and even then the TOC module was not functioning. Therefore, it was considered desirable to conduct Rock-Eval/TOC analyses on Leg 135 samples despite the unpromising organic geochemical results obtained on board the JOIDES Resolution (Parson, Hawkins, Allan, et al., 1992).

Sediment samples, from all eight sites cored during Leg 135 (Fig. 1), were analyzed by Rock-Eval/TOC analysis. Six of these sites were drilled in the Lau Basin backarc region (Sites 834-839), one on the Tongan Platform (Site 840), and one in the Tonga forearc region on the arc-trench slope (Site 841). The samples selected for analysis were either those sampled for carbonate and CNS analysis, or were a portion of the interstitial water squeezecake. These represent a biased sample set, as lithologies likely to have no organic carbon content were not selected (i.e., volcaniclastic intervals).

The results of the Rock-Eval/TOC analyses are given in Table 1. Parameters used in the table are defined in the "Experimental Methods" section (this chapter). As evident from the summary in Figure 2, the TOC contents of the Leg 135 samples are extremely low. Only one sample, from a depth of $65.56 \mathrm{~m}$ in Hole $834 \mathrm{~A}$, has a TOC content greater than $0.3 \%$. The average TOC content of the 156 samples is $0.05 \%$. As there was a tendency to avoid picking samples for organic geochemical analyses that were obviously predominately volcaniclastic, these values overestimate the average TOC content of the sediments recovered during Leg 135 . In comparison, the organic carbon contents of 148 samples analyzed on board the JOIDES Resolution, using the NCS analyzer to obtain total carbon and then subtracting the inorganic carbon value, was $0.14 \%$. Values up to $0.67 \%$ were obtained from this latter method. Hence, for a similar sample set, lower values were obtained from the Rock-Eval instrument at the Institute of Sedimentary and Petroleum Geology.

It should be emphasized that the Rock-Eval instrument is not designed for the analysis of samples with such low TOC contents; therefore, the results are not strictly accurate. Sources of errors inherent in the shipboard method will also be accentuated by samples that are very lean in organic carbon. Regardless of the absolute values, the results from both methods indicate that the organic carbon contents of the sediments recovered during Leg 135 are extremely low. This is in agreement with the results reported by previous workers who have analyzed sediments from this area. Buchbinder and Halley (1985) reported a TOC range from $0.09 \%$ to $0.42 \%$ for ten samples, with an average of $0.16 \%$; on the other hand, Sandstrom (1985) found a TOC range from $0.018 \%$ to $0.04 \%$, with an average of $0.025 \%$, for the eight samples he analyzed.

As the TOC contents and the $\mathrm{S}_{2}$ and $\mathrm{S}_{3}$ values are extremely low for all samples, the derived $\mathrm{HI}$ and $\mathrm{OI}$ values are questionable and 


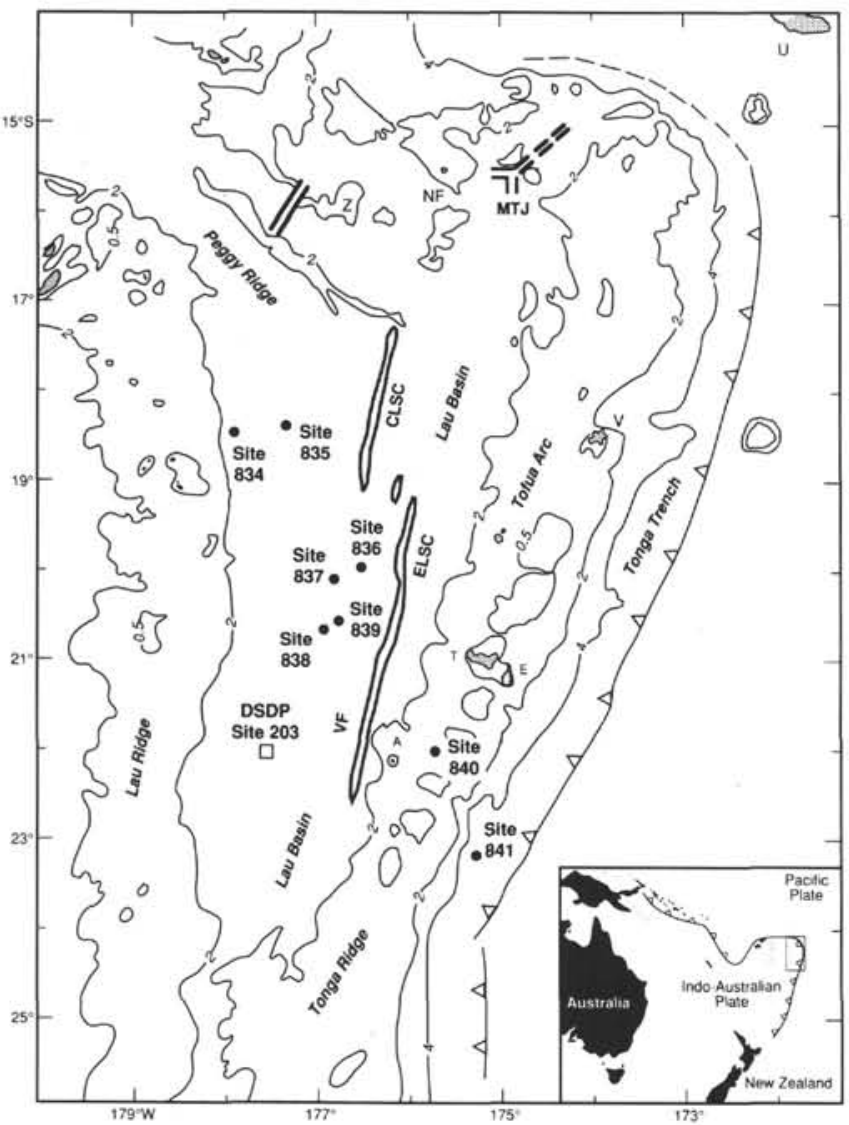

Figure I. Location of sites cored during Leg 135. Water depths in kilometers. Tongan Islands indicated are Tongatapu (T), 'Eua (E), 'Ata (A), Vava'u (V), $\mathrm{NF}=$ Niuafo' ${ }^{\circ}$, and $\mathrm{U}=\mathrm{Upolu}$.

probably meaningless. This is illustrated by the extremely high $\mathrm{OI}$ values given in Table 1, which are a function of the combination of a low TOC content and a possible contribution to the $S_{3}$ peak from carbonate (cf. Katz, 1983; Snowdon and Meyers, 1992). The very high $\mathrm{HI}$ values displayed by some samples are not related to an input of algal organic matter. They occur because of "small but multiplicative analytical errors in the TOC and $\mathrm{S}_{2}$ measurements" (Snowdon and Meyers, 1992) in these very low TOC samples. Also, no sample gave a large enough $S_{2}$ peak for the $T_{\max }$ value to be considered a reliable indicator of the thermal maturity of the organic matter. This

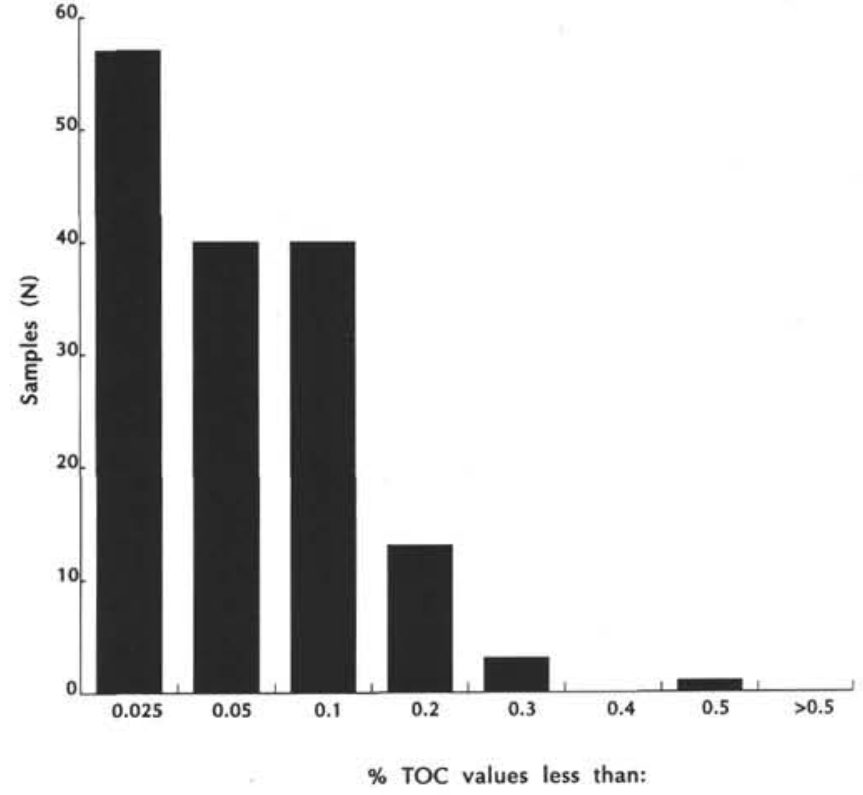

Figure 2. Histogram showing total organic carbon (TOC) contents of Leg 135 sediment samples.

is evident from the lack of any consistency or trend in $\mathrm{T}_{\max }$ values for any of the holes. However, the values for all these parameters are given in Table 1 for completeness.

It is not unexpected that open-ocean sediments with a large volcaniclastic contribution such as those cored during Leg 135 should have low TOC contents. Primary productivity in the upper waters of the open ocean is low (e.g., Tissot and Welte, 1984, p. 24), and efficient scavenging by organisms or oxidation in the water column means that sediments deposited in such areas normally contain a low abundance of organic carbon (e.g., Hunt, 1979, p. 104). The addition of volcaniclastic sediments further dilutes this carbon, which is, in any case, mostly inertinite with no metabolic value for bacteria. The lack of enough carbon for the sulfate-reducing bacteria to metabolize is possibly the reason why sulfate levels at the Leg 135 sites show little change with depth and also why methane was not detected above background levels in any of the head-space samples taken during Leg 135 (Parson, Hawkins, Allan, et al., 1992). Hence, two of the diagenetic stages that are generally observed in marine sediments, sulfate reduction and methanogenesis (Curtis, 1987), do not occur in Leg 135 sediments, which should have important consequences for the diagenesis of inorganic species.

Table 2. Data from extraction, fractionation, and gas chromatographic analysis for ten Leg 135 sediment samples and Pili oil seep.

\begin{tabular}{|c|c|c|c|c|c|c|c|c|c|c|c|}
\hline $\begin{array}{l}\text { Core, section, } \\
\text { interval (cm) }\end{array}$ & $\begin{array}{l}\text { Depth } \\
\text { (mbsf) }\end{array}$ & $\begin{array}{l}\text { TOC } \\
\text { (\%) }\end{array}$ & $\begin{array}{c}\text { Extract } \\
\text { yield } \\
\text { ( } \mathrm{mg} / \mathrm{g} \\
\text { orgC) }\end{array}$ & $\begin{array}{c}\mathrm{HC} \\
\text { yield } \\
\text { (mg/g } \\
\text { orgC) }\end{array}$ & $\begin{array}{l}\mathrm{HC} \\
(\%)\end{array}$ & $\begin{array}{l}R+A \\
(\%)\end{array}$ & $\begin{array}{l}\text { Saturate } \\
\text { (\%) }\end{array}$ & $\begin{array}{l}\text { Aromatic } \\
(\%)\end{array}$ & $\mathrm{pr} / \mathrm{ph}$ & $\mathrm{pr} / \mathrm{nC}_{17}$ & $\mathrm{nC}_{17} / \mathrm{nC}_{27}$ \\
\hline $135-834 \mathrm{~A}-1 \mathrm{H}-4,140-150$ & 5.90 & 0.03 & 2.7 & 0.2 & 7.41 & 74.07 & 3.70 & 3.70 & 0.65 & 0.91 & 0.50 \\
\hline $135-835 \mathrm{~A}-1 \mathrm{H}-4,140-150$ & 5.90 & 0.05 & 3.7 & 0.6 & 16.22 & 73.00 & 5.41 & 10.81 & 0.75 & 0.63 & 3.06 \\
\hline $135-836 \mathrm{~A}-2 \mathrm{H}-4,140-150$ & 7.10 & 0.02 & 3.8 & 0.4 & 10.53 & 81.58 & 5.26 & 5.26 & 0.75 & 1.21 & 1.55 \\
\hline $135-837 \mathrm{~A}-4 \mathrm{H}-4,140-150$ & 32.90 & 0.02 & 3.6 & 0.3 & 8.33 & 72.22 & 2.78 & 5.56 & 0.57 & ND & ND \\
\hline $135-839 \mathrm{~A}-3 \mathrm{H}-4,140-150$ & 19.90 & 0.04 & 5.5 & 0.7 & 12.73 & 70.91 & 5.45 & 7.27 & 0.60 & 0.88 & ND \\
\hline $135-840 \mathrm{C}-5 \mathrm{H}-1.139-147$ & 125.39 & 0.07 & 2.9 & 0.4 & 13.79 & 65.52 & 6.90 & 6.90 & 0.80 & 2.06 & ND \\
\hline $135-841 \mathrm{~A}-2 \mathrm{H}-4,140-150$ & 14.40 & 0.09 & 3.1 & 0.2 & 6.45 & 83.87 & 3.23 & 3.23 & 0.71 & 2.16 & 2.40 \\
\hline $135-841 \mathrm{~A}-3 \mathrm{H}-4,140-150$ & 23.90 & 0.07 & 3.7 & 0.5 & 13.51 & 56.76 & 5.41 & 8.11 & 0.61 & 0.67 & 2.27 \\
\hline $135-841 \mathrm{~A}-4 \mathrm{H}-4,140-150$ & 33.40 & 0.03 & 2.8 & 0.4 & 14.29 & 67.86 & 3.57 & 10.71 & 0.62 & 1.44 & 1.42 \\
\hline $135-841 \mathrm{~A}-6 \mathrm{H}-4,140-150$ & 52.40 & 0.05 & 2.9 & 0.5 & 17.24 & 79.31 & 6.90 & 10.34 & 0.64 & 1.04 & 0.07 \\
\hline Pili oil seep & & & & & 81.24 & 17.72 & 34.56 & 46.80 & 0.85 & & \\
\hline
\end{tabular}

Notes: $\mathrm{TOC}=$ total organic carbon as weight percent of the whole rock; $\mathrm{HC}=$ percentage of hydrocarbons in total extract: $\mathrm{R}+\mathrm{A}=$ percentage of resins and asphaltenes in total extract; $\mathrm{pr} / \mathrm{ph}=$ pristane/phytane: $\mathrm{pr} / \mathrm{nC}_{17}=$ pristane $/ \mathrm{n}$-heptadecane; and $\mathrm{C}_{17} / \mathrm{C}_{27}=\mathrm{n}$-heptadecane/n-heptacosane. ND = not determined because compounds present in such low concentrations. 

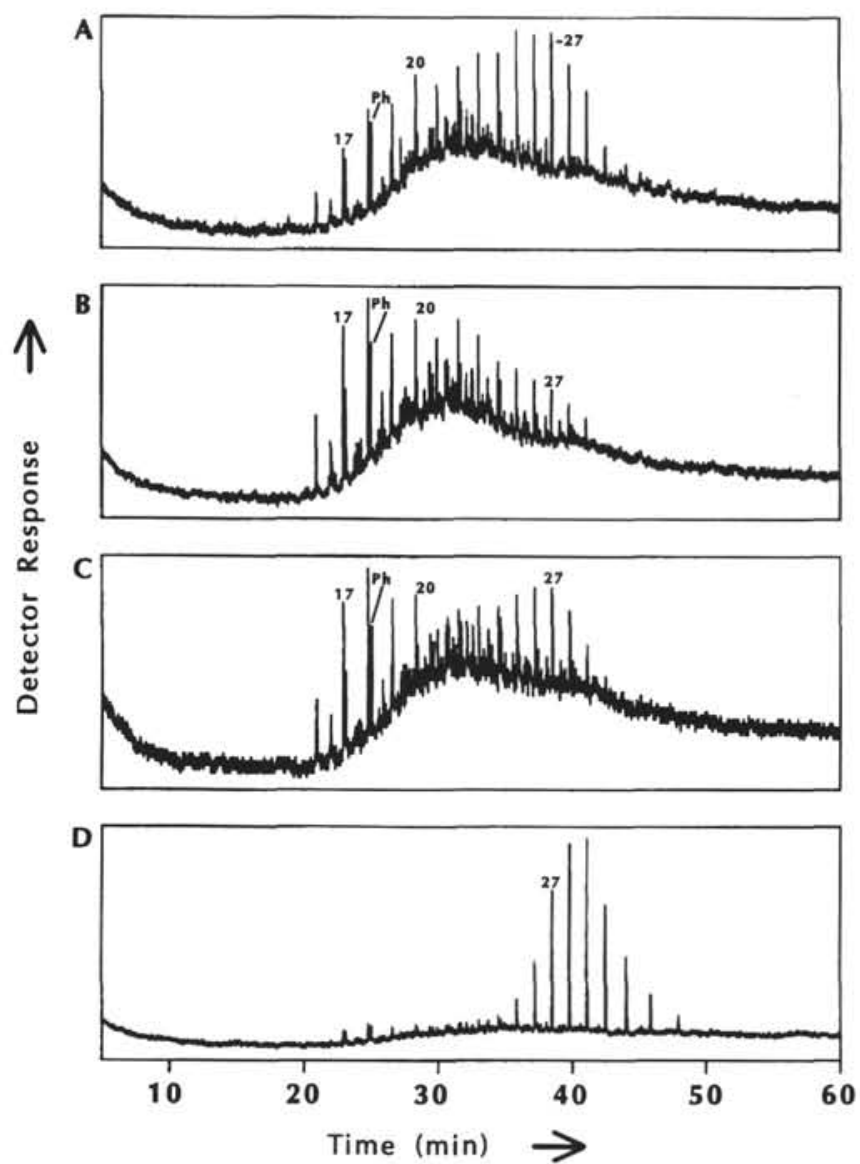

Figure 3. Representative saturate fraction gas chromatograms of Leg 135 samples. A. Sample 135-834A-1H-4 (5.9 mbsf). B. Sample 135-835A-1H-4 (5.9 mbsf). C. Sample 135-840C-5H-1 (125.39 mbsf). D. Sample 135-841 A$6 \mathrm{H}-4$ ( $52.4 \mathrm{mbsf}$ ). The numbers 17,20 , and 27 represent the $\mathrm{C}_{17}, \mathrm{C}_{20}$. and $\mathrm{C}_{27}$ $\mathrm{n}$-alkanes, and $\mathrm{Ph}=$ phytane.

\section{HYDROCARBON ANALYSES OF LEG 135 SEDIMENTS}

Ten samples were selected for extraction and analysis of their saturate fractions using the criteria and methodology outlined in the "Experimental Methods" section (this chapter). As indicated by the extract and hydrocarbon yields (Table 2), the amounts of total extractable organic matter and hydrocarbons obtained from these samples were extremely small. Only $0.1-0.3 \mathrm{mg}$ of saturate hydrocarbons were obtained from powdered rock samples ranging from 7.8 to 17.17 g. These are such low amounts that the possibility of contamination must be considered very great.

The saturate fraction gas chromatograms (SFGCs) display a low signal-to-noise ratio (Fig. 3). The n-alkanes are the predominant peaks in all the SFGCs, with the acyclic isoprenoids (e.g., pristane and phytane) also present in high relative abundance in most samples (Table 2, $\mathrm{pr} / \mathrm{nC}_{17}$ ). Some SFGCs show a predominance of the $\mathrm{C}_{15}-\mathrm{C}_{20}$ and others a predominance of the $\mathrm{C}_{20+} \mathrm{n}$-alkanes (Table $2, \mathrm{nC}_{17} / \mathrm{nC}_{27}$ ), implying that some samples have received mostly marine organic and others mostly terrestrial organic matter (Tissot and Welte, 1984). All the samples have low pristane/phytane ratios that could, for example, suggest anoxic conditions of deposition (Didyk et al., 1978); however, as evident from the SFGCs (Fig. 3), this is more likely a result of evaporative losses during the workup of such small amounts.

The terpane and sterane distributions were examined by GC-MSMID (Figs. 4-5). Several aspects of the distributions of these compounds exist that suggest they are not representative of the organic

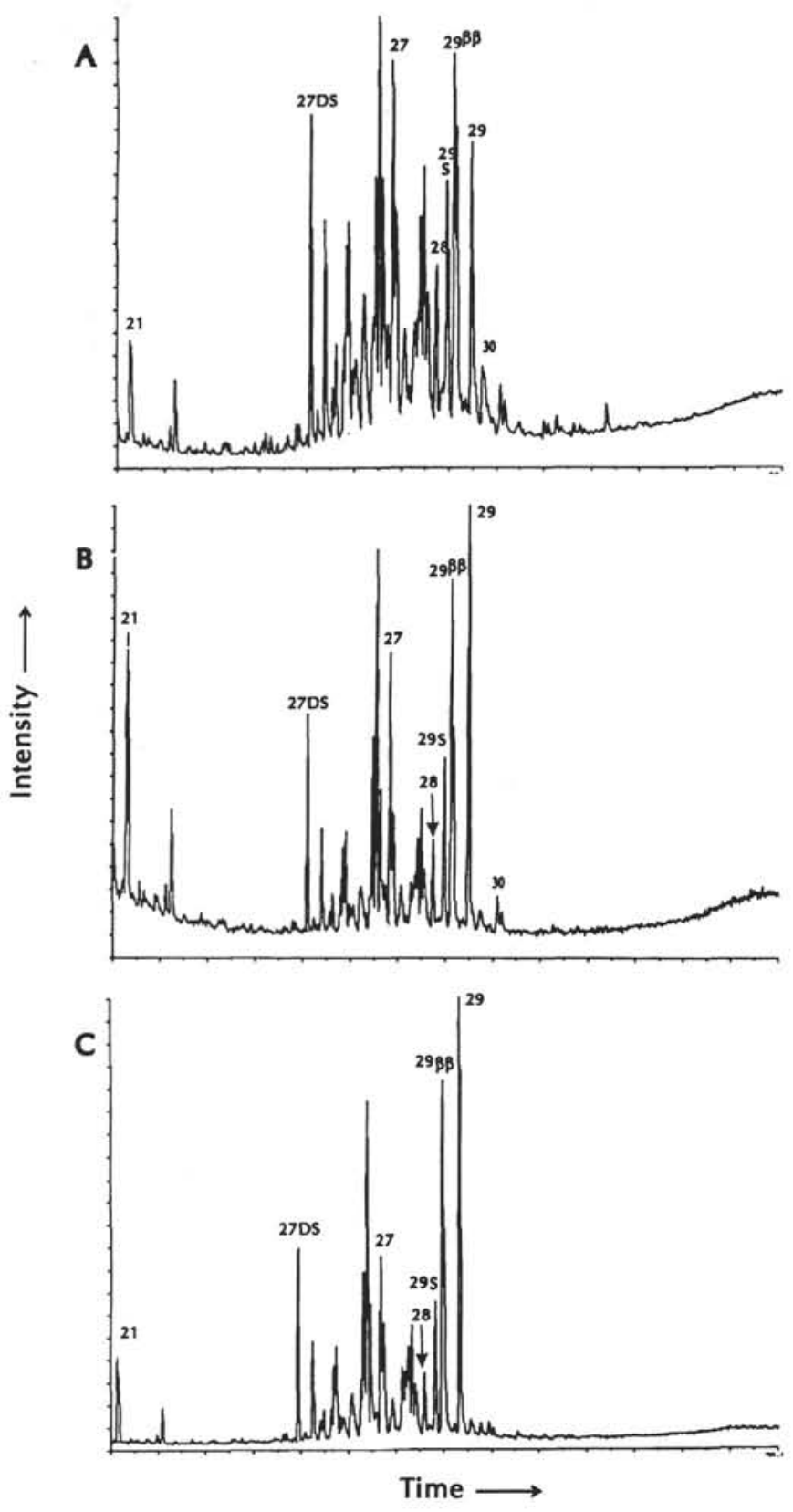

Figure 4. Representative $\mathrm{m} / \mathrm{z} 217$ mass fragmentograms showing the distributions of steranes in Leg 135 samples. A. Sample 135-834A-1H-4 (5.9 mbsf). B. Sample 135-840C-5H-I (125.39 mbsf). C. Sample 135-841 A-6H-4 (52.4 mbsf). The numbers 27,28 , and 29 represent the $\mathrm{C}_{27}, \mathrm{C}_{28}$, and $\mathrm{C}_{29} 5 \alpha(\mathrm{H}), 14 \alpha(\mathrm{H})$, $17 \alpha(\mathrm{H})$-20R steranes; $29 \mathrm{~S}$ represents the $\mathrm{C}_{29} 5 \alpha(\mathrm{H}), 14 \alpha(\mathrm{H}), 17 \alpha(\mathrm{H})-20 \mathrm{~S}$ sterane; $29 \beta \beta$ represents the $\mathrm{C}_{29} 5 \alpha(\mathrm{H}), 14 \beta(\mathrm{H}), 17 \beta(\mathrm{H})$ steranes; $27 \mathrm{DS}$ is the $\mathrm{C}_{27}$ $13 \beta(\mathrm{H}), 17 \alpha(\mathrm{H})-20 \mathrm{~S}$ diasterane; and 21 and 30 are the $\mathrm{C}_{21}$ and $\mathrm{C}_{30}$ steranes, respectively.

matter of these samples and are contamination. The maturity of the samples, as indicated by biomarker maturation parameters (e.g., Mackenzie, 1984), is much greater than would be expected for their depth (e.g., the following ratios in Table 3: $20 \mathrm{~S}$ to $20 \mathrm{R} 5 \alpha(\mathrm{H}), 14 \alpha(\mathrm{H})$, $17 \alpha(\mathrm{H})$ steranes, $5 \alpha(\mathrm{H}), 14 \beta(\mathrm{H}), 17 \beta(\mathrm{H})$ to $5 \alpha(\mathrm{H}), 14 \alpha(\mathrm{H}), 17 \alpha(\mathrm{H})$ steranes, $17 \alpha(\mathrm{H}), 21 \beta(\mathrm{H})$-hopane/17 $\beta(\mathrm{H}), 21 \alpha(\mathrm{H})$-moretane, and the $\mathrm{C}_{32} 17 \alpha(\mathrm{H}), 21 \beta(\mathrm{H}) 22 \mathrm{~S}$ and $22 \mathrm{R}$ hopanes). These ratios imply that most of the samples are marginally mature with respect to hydrocarbon generation, although their present depths range only from 5.9 to 125.39 mbsf. Also, these and other parameters that are normally thought to be 

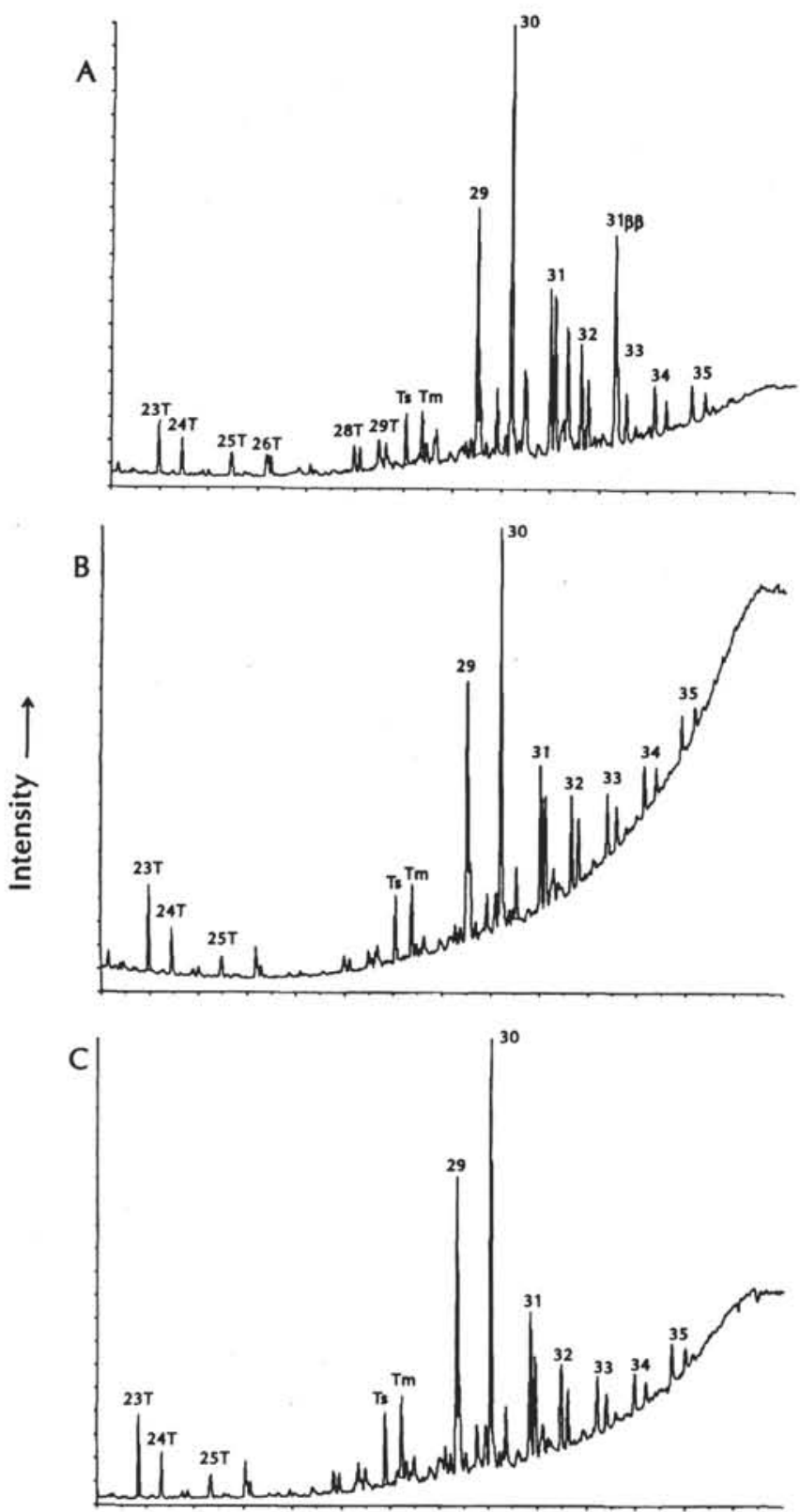

Time

Figure 5. Representative $\mathrm{m} / \mathrm{z} 191$ fragmentograms showing the distributions of terpanes in Leg 135 samples. A. Sample 135-834A-1 H-4 (5.9 mbsf). B. Sample 135-840C-5H-1 (125.39 mbsf). C. Sample 135-841 A-6H-4 (52.4 mbsf). The labels $23 \mathrm{~T}-29 \mathrm{~T}$ represent the $\mathrm{C}_{23}-\mathrm{C}_{29}$ tricyclic terpanes; $29-35$ are the $\mathrm{C}_{29}-\mathrm{C}_{35} 17 \alpha(\mathrm{H})$-hopanes; $\mathrm{Ts}$ is $18 \alpha(\mathrm{H})$-trisnorhopane; $\mathrm{Tm}$ is $17 \alpha(\mathrm{H})$-trisnorhopane; and $31 \beta \beta$ is $\mathrm{C}_{31} 17 \beta(\mathrm{H}), 21 \beta(\mathrm{H})$-homohopane.

more source dependent (e.g., ratio of $\mathrm{C}_{27}: \mathrm{C}_{28}: \mathrm{C}_{29}$ steranes, ratio of diasteranes to regular steranes, $\mathrm{Ts} / \mathrm{Tm}$, etc.; Table 3 ), suggest that all the samples had a contribution from a similar mix of organic material, regardless of site or stratigraphic horizon. Some differences are present between the samples, such as the sterane distribution of the sample from a depth of $52.4 \mathrm{mbsf}$, in Hole 841A (Fig. 4C), which has significantly lower $\mathrm{C}_{29} \mathrm{~S} / \mathrm{R}$ and $\mathrm{C}_{21} / \mathrm{C}_{29}$ sterane ratios (Table 3), and the hopane distribution of the sample from $5.9 \mathrm{mbsf}$, in Hole 834A, which has higher amounts of $17 \beta(\mathrm{H}), 21 \alpha(\mathrm{H})$-moretanes and $17 \beta(\mathrm{H}), 21 \beta(\mathrm{H})$ hopanes compared with other samples (Fig. 5A; hopane/moretane in Table 3). In the case of this latter sample, its hopane distribution indi-

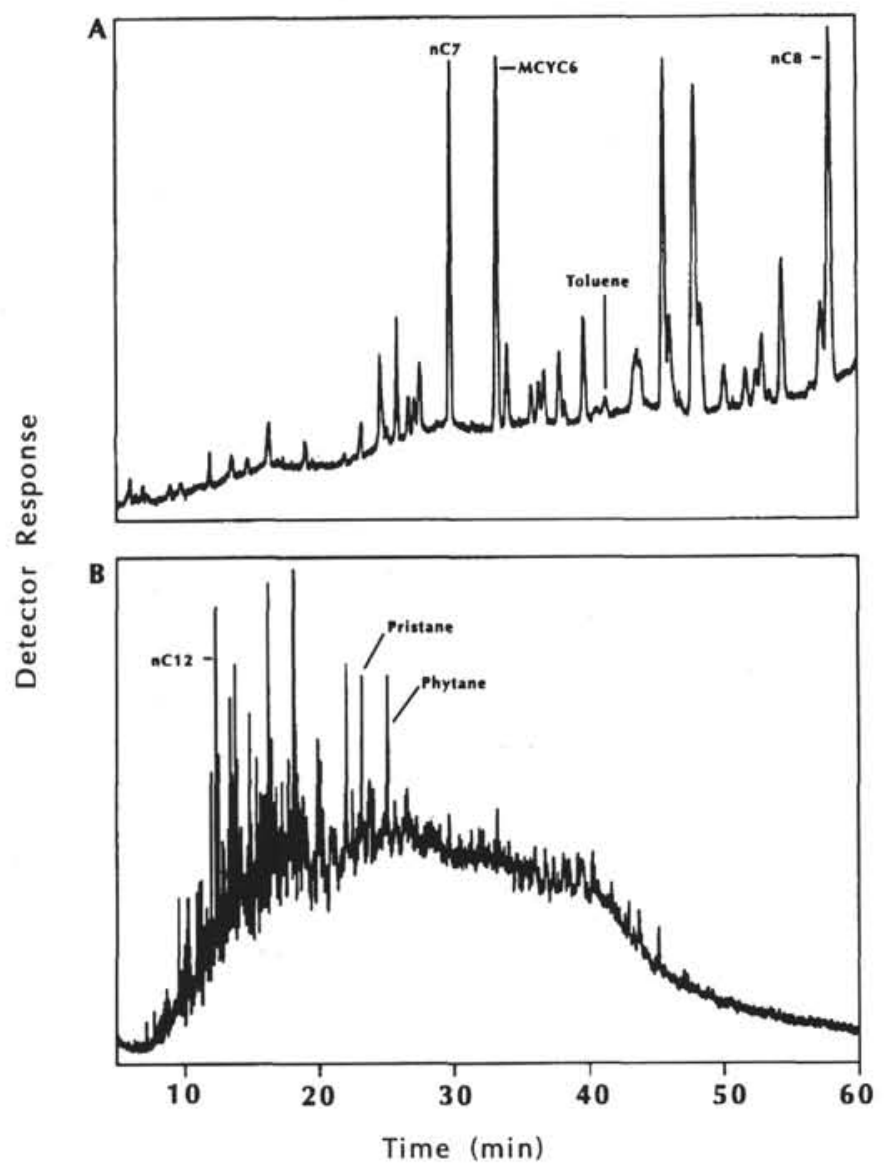

Figure 6. A. Gasoline range $\left(\mathrm{C}_{6}-\mathrm{C}_{8}\right)$ chromatogram of Pili oil seep sample. MCYC6 is methylcyclohexane. B. Saturate fraction gas chromatogram of Pili oil seep sample.

cates that it is the least mature, whereas its sterane distribution suggests that it is the most mature of the samples. The variations in the $\mathrm{m} / \mathrm{z} 191$ and 217 fragmentograms may be because indigenous hydrocarbons do in fact comprise a portion of the extracted saturate hydrocarbon fraction of some samples. Biomarkers are present in such low concentrations in these samples that the level of contamination would not need to be very great for their distributions to have been affected.

\section{GEOCHEMISTRY OF PILI OIL SEEP}

A sample of an oil seep from Tongatapu was obtained from Sione Soakai of the Ministry of Lands, Surveys and Natural Resources, Tonga. The results of an analysis of this sample were compared with the results obtained from samples collected and analyzed in the early 1980s (Sandstrom and Philp, 1984; Sandstrom, 1985) and used to suggest the nature of source of the seeps.

The sample analyzed here originated from Pili, in the southern outskirts of Nuku'alofa, Tongatapu. It arrived in a jar $(\approx 0.5$ liter $)$ as a mass of oil floating on water (ratio of oil:water $\approx 1: 1$ ). A minor amount of vegetable matter was also in the jar.

The sample consisted mostly of hydrocarbons with aromatics predominating over saturates (Table 2). The high proportion of hydrocarbons suggests that this is a migrated oil. The five samples from Hofoa and Fasi analyzed by Sandstrom and Philp (1985) contained much lower amounts of hydrocarbons $(20.7 \%-40.9 \%$ vs. $81.24 \%)$, possibly because they were more biodegraded. The ratio of saturates to aromatics $(0.74)$ falls into the upper part of the range of values reported by Sandstrom and Philp (1984). 
Table 3. Sterane and terpane biomarker ratios for ten Leg 135 sediment samples and Pili oil seep.

\begin{tabular}{|c|c|c|c|c|c|c|c|c|c|c|c|c|c|}
\hline $\begin{array}{l}\text { Core, section, } \\
\text { interval }(\mathrm{cm})\end{array}$ & $\begin{array}{l}\text { Depth } \\
\text { (mbsf) }\end{array}$ & $\begin{array}{l}\mathrm{C}_{29} \\
\mathrm{~S} / \mathrm{R}^{4}\end{array}$ & $\begin{array}{c}\mathrm{C}_{29} \alpha \beta \beta / \\
\alpha \beta \bar{\beta}+\alpha \alpha \alpha^{b}\end{array}$ & $\begin{array}{l}\mathrm{C}_{27} \\
\mathrm{D} / \mathrm{R}^{6}\end{array}$ & $\mathrm{C}_{21} / \mathrm{C}_{29}{ }^{d}$ & $\mathrm{C}_{27}{ }^{\mathrm{e}}$ & $\mathrm{C}_{28}{ }^{\mathrm{e}}$ & $\mathrm{C}_{29}{ }^{\mathrm{c}}$ & $29 / 30^{f}$ & $\mathrm{Ts} / \mathrm{Tm} \mathrm{g}^{\mathrm{g}}$ & $\begin{array}{c}C_{30} \\
\alpha \beta / \beta \alpha^{h}\end{array}$ & $\begin{array}{c}\mathrm{C}_{32} \\
\mathrm{~S} / \mathrm{S}+\mathrm{R}^{\mathrm{i}}\end{array}$ & $\mathrm{C}_{2,8} / \mathrm{C}_{30}$ \\
\hline $135-834 \mathrm{~A}-1 \mathrm{H}-4,140-150$ & 5.90 & 0.85 & 0.57 & 1.09 & 0.40 & 30 & 26 & 44 & 0.57 & 1.13 & 5.22 & 1.59 & 0.13 \\
\hline $135-836 \mathrm{~A}-2 \mathrm{H}-4,140-150$ & 7.10 & 0.57 & 0.50 & 0.89 & 0.53 & 31 & 20 & 49 & 0.69 & 0.95 & 8.75 & 1.50 & 0.19 \\
\hline $135-837 \mathrm{~A}-4 \mathrm{H}-4,140-150$ & 32.90 & 0.53 & 0.49 & 1.00 & 0.52 & 30 & 22 & 48 & 0.74 & 0.92 & 7.32 & 1.55 & 0.19 \\
\hline $135-839 \mathrm{~A}-3 \mathrm{H}-4,140-150$ & 19.90 & 0.54 & 0.50 & 0.93 & 0.53 & 30 & 20 & 50 & 0.69 & 1.00 & 11.00 & 1.43 & 0.20 \\
\hline $135-840 \mathrm{C}-5 \mathrm{H}-1,139-147$ & 125.39 & 0.40 & 0.48 & 0.85 & 0.64 & 29 & 16 & 55 & 0.65 & 0.88 & 10.80 & 1.48 & 0.22 \\
\hline $135-841 \mathrm{~A}-3 \mathrm{H}-4,140-150$ & 23.90 & 0.53 & 0.48 & 0.99 & 0.68 & 30 & 21 & 49 & 0.65 & 0.96 & 7.82 & 1.60 & 0.21 \\
\hline $135-841 \mathrm{~A}-4 \mathrm{H}-4,140-150$ & 33.40 & 0.44 & 0.48 & 0.93 & 0.58 & 38 & 16 & 46 & 0.68 & 0.89 & 8,41 & 1.24 & 0.27 \\
\hline $135-841 \mathrm{~A}-6 \mathrm{H}-4,140-150$ & 52.40 & 0.30 & 0.48 & 1.12 & 0.20 & 32 & 18 & 50 & 0.69 & 0.85 & 7.72 & 1.47 & 0.19 \\
\hline Pili oil seep & & 0.97 & 0.61 & 0.59 & 1.50 & 36 & 32 & 32 & 0.88 & 0.55 & 14.90 & 1.49 & 0.82 \\
\hline
\end{tabular}

Notes: Results for Pili samples are from GC-MS-MS, which gave similar values to the GC-MS-MID analysis except for the $\mathrm{C}_{27}: \mathrm{C}_{28}: \mathrm{C}_{29} 5 \alpha(\mathrm{H}), 14 \alpha(\mathrm{H}), 17 \alpha(\mathrm{H}) 20 \mathrm{R}$ ratio. which is different from the ratio of $5 \alpha(\mathrm{H}) .14 \beta(\mathrm{H}) .17 \beta(\mathrm{H})$ steranes obtained from the $\mathrm{m} / z .218$ fragmentograms. The $\mathrm{C}_{27}: \mathrm{C}_{28}: \mathrm{C}_{29} 5 \alpha(\mathrm{H}), 14 \alpha(\mathrm{H}), 17 \alpha(\mathrm{H}) 20 \mathrm{R}$ ratio for the Pili oil seep determined by GC-MS-MS analysis is 44:26:30.

$5 \alpha(\mathrm{H}), 14 \alpha(\mathrm{H}), 17 \alpha(\mathrm{H}) 20 \mathrm{~S} / 5 \alpha(\mathrm{H}), 14 \alpha(\mathrm{H}), 17 \alpha(\mathrm{H}) 20 \mathrm{R}-\mathrm{C}_{29}$ sterane.

${ }^{\mathrm{b}} 5 \alpha(\mathrm{H}), 14 \beta(\mathrm{H}), 17 \beta(\mathrm{H}) / 5 \alpha(\mathrm{H}), 14 \beta(\mathrm{H}), 17 \beta(\mathrm{H})+5 \alpha(\mathrm{H}), 14 \alpha(\mathrm{H}) 17 \alpha(\mathrm{H}) \mathrm{C}_{29}$ steranes.

" $13 \beta(\mathrm{H}), 17 \alpha(\mathrm{H}) 20 \mathrm{~S}$-diacholestane/5 $\alpha(\mathrm{H}), 14 \alpha(\mathrm{H}), 17 \alpha(\mathrm{H})$ 20R-cholestane.

${ }^{d} \mathrm{C}_{21}$ sterane/ $5 \alpha(\mathrm{H}), 14 \alpha(\mathrm{H}), 17 \alpha(\mathrm{H}) 20 \mathrm{R}-\mathrm{C}_{29}$ sterane.

"Normalized proportion of $\mathrm{C}_{27}: \mathrm{C}_{28}: \mathrm{C}_{29} 5 \alpha(\mathrm{H}), 14 \beta(\mathrm{H}), 17 \beta(\mathrm{H})$ steranes from $\mathrm{m} / \mathrm{z} 218$ fragmentograms.

${ }_{1} 17 \alpha(\mathrm{H})$-norhopane/17 $\alpha(\mathrm{H})$-hopane.

${ }^{g} 18 \alpha(\mathrm{H})$-trisnorhopane/17 $\alpha(\mathrm{H})$-trisnorhopane.

${ }^{h} 17 \alpha(\mathrm{H})$-hopane/17 $\beta(\mathrm{H})$-moretane.

$22 \mathrm{~S} / 22 \mathrm{~S}+22 \mathrm{R} 17 \alpha(\mathrm{H})$-bishomohopanes.

${ }^{j} \mathrm{C}_{23}$ tricyclic terpane/17 $\alpha(\mathrm{H})$-hopane.

The gasoline-range hydrocarbons of the Pili sample (Fig. 6A) are dominated by n-alkanes and cyclic compounds. Aromatics such as benzene and toluene are present in very low amounts, suggesting that this sample has been affected by water-washing. The chromatogram has lower than normal amounts of $\mathrm{C}_{6}$ relative to $\mathrm{C}_{7}$ hydrocarbons, presumably because of the preferential loss of lighter compounds before or during transportation.

The Pili oil seep SFGC consists of a large hump of unresolved compounds with some discrete peaks superimposed, including the $\mathrm{C}_{14}-\mathrm{C}_{20}$ acyclic isoprenoids (Fig. 6B). This is consistent with the sample having undergone moderate biodegradation (Volkman et al., 1983). The SFGC appears to show the presence of the $C_{12}$ and $C_{13} n-$ alkanes. The occurrence of these compounds and the $\mathrm{C}_{6}-\mathrm{C}_{8}$ n-alkanes in the gasoline-range fraction implies that mixing of biodegraded hydrocarbons and light unbiodegraded hydrocarbons has occurred. This suggests that the seep is presently active with the addition of hydrocarbons from a more mature source to those previously generated and subsequently biodegraded. Alternately, the source rock may be of similar maturity at present, but preferential migration of lighter hydrocarbons is occurring to the site of the seep.

The saturate hydrocarbons were analyzed by three different GCMS techniques: GC-MS-MID to look at the distributions of steranes and terpanes, GC-MS-MS to look at the distributions of some of these compounds with greater specificity, and GC-MS in full scan mode to look at the distribution of other compound classes and to obtain mass spectra for the identification of certain peaks. In addition, the distribution of triaromatic steranes was monitored. No evidence was obtained from any of these analyses that the biomarkers had been affected by biodegradation. For example, the 25-norhopanes reported by Sandstrom and Philp (1984) in their seep samples were not detected in the Pili sample.

The steranes (Fig. 7A and Table 3 ) show a mature distribution, with the ratios of the $20 \mathrm{~S}$ and $20 \mathrm{R} 5 \alpha(\mathrm{H}), 14 \alpha(\mathrm{H}), 17 \alpha(\mathrm{H})$ steranes and the $5 \alpha(\mathrm{H}), 14 \beta(\mathrm{H}), 17 \beta(\mathrm{H})$ to $5 \alpha(\mathrm{H}), 14 \alpha(\mathrm{H}), 17 \alpha(\mathrm{H})$ steranes near their equilibrium values (Mackenzie, 1984). A low abundance of diasteranes relative to the regular steranes, as displayed by this sample, is normally shown by carbonates and their derived oils (McKirdy et al., 1983). The relative abundance of the $\mathrm{C}_{27}: \mathrm{C}_{28}: \mathrm{C}_{29}$ regular steranes suggests a Cretaceous- to Tertiary-aged source rock (Grantham and Wakefield, 1988). This is also indicated by the ratio of $C_{27}$ to $C_{28}$ triaromatic steranes $([26 \mathrm{R}+27 \mathrm{~S}]-26 \mathrm{~S} / 28 \mathrm{~S}=2.06$; Fig. $7 \mathrm{C})$, which also show a trend through geological time (P.W. Brooks, pers. comm., 1992). Other steroidal compounds identified in this sample are $\mathrm{C}_{30}$ regular steranes and $\mathrm{C}_{28}-\mathrm{C}_{30}$ 4-methylsteranes with the $\mathrm{C}_{30}$ members having a dinosterol-derived skeleton. The presence of these compounds indicates a contribution from dinoflagellates and other marine algae to the organic matter of the source rock (Summons et al., 1987; Moldowan et al. 1990). The $C_{27}-C_{29}$ tricyclic compounds that show a major fragment ion of $\mathrm{m} / \mathrm{z} 219$ and are thought to be derived from steroidal compounds (Jiang et al., 1990) were also detected.

The $\mathrm{m} / \mathrm{z} 191$ mass fragmentogram of the Pili oil seep shows a mature distribution of the $17 \alpha(\mathrm{H})$-hopanes (Fig. 7B). Tricyclic terpanes are also present in high abundance. The relatively low Ts/Tm ratio (Table 3) is further evidence of a probable carbonate source for these hydrocarbons (McKirdy et al., 1983). Also detected were the $\mathrm{C}_{29}$ and $\mathrm{C}_{30} 8,14$-secohopanes and the $\mathrm{C}_{28}$ 28,30-bisnorhopane. A small peak with the correct retention time for $18 \alpha$-oleanane was detected by both GC-MS (Fig. 7B) and GC-MS-MS (using the $\mathrm{m} / \mathrm{z} 412 \rightarrow 191$ transition) methods. This peak was not in high enough abundance to obtain a mass spectrum good enough to confirm this identification. If oleanane is present, then a minor contribution from Late CretaceousTertiary higher land plant material to the organic matter of the source rock is indicated (Moldowan et al., 1991). It is unlikely that the oleanane originated from the plant material in the jar with the oil sample. This is because a degree of thermal maturation is required to form oleanane from its precursors (ten Haven and Rullkötter, 1988).

Other classes of compounds identified within the oil seep were regular head-to-tail acyclic isoprenoids up to $C_{40}, C_{12}-C_{20} n$-alkylcyclohexanes, and bicyclic alkanes with the drimane skeleton (Alexander et al., 1984). None of these compounds have a specific biological precursor.

\section{DISCUSSION AND CONCLUSIONS ON THE ORIGIN OF TONGATAPU OIL SEEPS}

The $\mathrm{m} / \mathrm{z} 191$ and 217 mass fragmentograms of the Pili sample (Fig. 7) show a close resemblance to those of the less degraded samples from Fasi and Hofoa published by Sandstrom and Philp (1984). The only difference is that their samples have a higher abundance of tricyclic terpanes relative to $17 \alpha(\mathrm{H})$-hopane than the Pili sample. This 

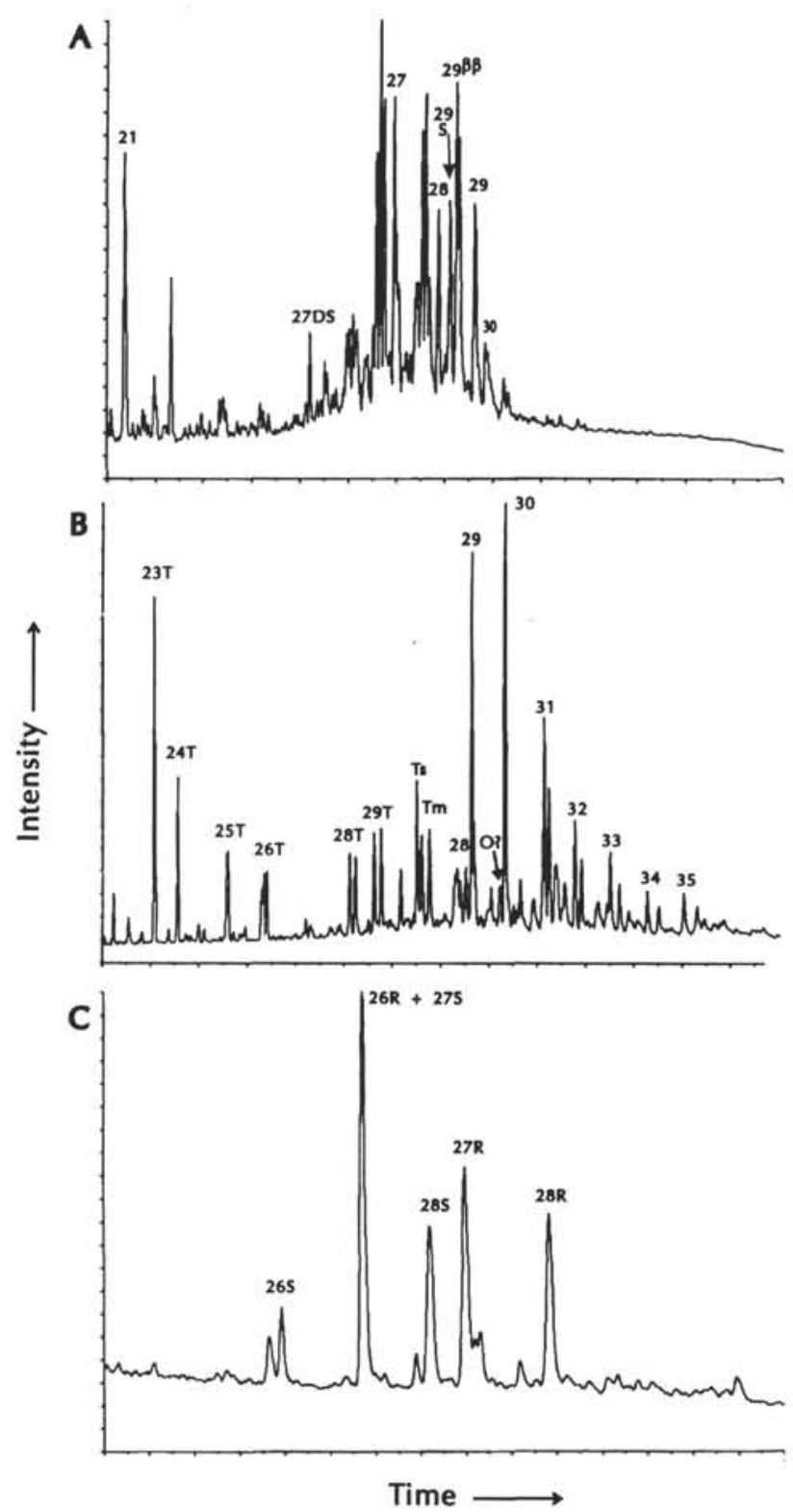

Figure 7. Mass fragmentograms showing distributions of biomarkers in Pili oil seep sample. A. The $\mathrm{m} / \mathrm{z} 217$ fragmentogram showing sterane distribution. B. The $\mathrm{m} / \mathrm{z} 191$ fragmentogram showing terpane distribution (28 is bisnorhopane). C. The $\mathrm{m} / \mathrm{z} 231$ fragmentogram showing triaromatic sterane distribution. The annotation for Figures 7A and 7B is as for Figures 4 and 5 except for $\mathrm{O}$ ? in Figure $7 \mathrm{~B}$, which indicates the peak that is possibly $18 \alpha$-oleanane. For Figure $7 \mathrm{C}$, the numbers 26,27 , and 28 are the carbon numbers of the triaromatic steranes, with $\mathrm{S}$ and $\mathrm{R}$ referring to the stereochemistry of the $\mathrm{C} 20$ position.

would be expected because even the less degraded samples analyzed by Sandstrom and Philp (1984) were more severely biodegraded than the Pili oil seep.

The Pili sample was collected during 1991, whereas the samples analyzed by Sandstrom and Philp (1984) were collected during 1982. The close similarity between the geochemical signatures of samples collected from different locations and $9 \mathrm{yr}$ apart is strong evidence against these seeps having an anthropogenic origin. Hence, it is likely that they have been generated from a mature source rock in the vicinity of Tongatapu and migrated into their present location where they have been moderately biodegraded. Geochemical evidence suggests that the source rock is a marine carbonate of probable Cretaceous-Early Tertiary age. As this is not unreasonable for this geological setting, it is additional evidence for the hydrocarbons to have been derived from a local source. The presence of light hydrocarbons that are not biodegraded suggests either that the seep is active, with the source rock still generating hydrocarbons, or that there has been some contamination by lighter hydrocarbons.

The source of the Tongatapu oil seeps remains to be discovered. The results from the Rock-Eval/TOC analysis of Leg 135 samples and the data published by previous workers (Buchbinder and Halley, 1985; Sandstrom, 1985) do not indicate any potential source rocks in the vicinity of Tonga that could possibly be responsible for the seeps on Tongatapu. Eocene limestones equivalent to those exposed on 'Eua and possibly related to those drilled on the Tongan forearc at Site 841 (Unit V, 549.1-605.0 mbsf; Parson, Hawkins, Allan, et al., 1992, pp. 625-628) are thought to be the most likely source (Gatliff, 1990). However, the lithologic features of the Eocene sediments recovered from Hole $841 \mathrm{~B}$ do not appear to indicate anoxic bottom waters during deposition and consequently do not seem favorable for the development of source rock facies. This is evident from the low TOC contents of these sediments.

\section{ACKNOWLEDGMENTS}

I thank Ross Stewart, Sneh Achal, and Marg Northcott for their excellent technical assistance, and the Geological Survey of Canada and the Ocean Drilling Program for the opportunity to be a shipboard scientist on Leg 135. This is Geological Survey of Canada Contribution No. 16992

\section{REFERENCES}

Alexander, R., Kagi, R.I., Noble, R., and Volkman, J.K., 1984. Identification of some bicyclic alkanes in petroleum. Org. Geochem., 6:63-70.

Buchbinder, B., and Halley, R.B., 1985. Source rock evaluation of outcrop and borehole samples from Tongatapu and 'Eua Islands, Tonga, and from Viti Levu and Vanua Levu Islands, Fiji. In Scholl, D.W., and Vallier, T.L. (Eds.), Geology and Offshore Resources of Pacific Island Arcs-Tonga Region. Circum-Pac. Counc. Energy Miner. Resour., Earth Sci. Ser., 2:335-349.

Curtis, C.D., 1987. Inorganic geochemistry and petroleum exploration. In Brooks, J., and Welte, D. (Eds.), Advances in Petroleum Geochemistry (Vol. 2): London (Academic Press), 91-140.

Didyk, B.M., Simoneit, B.R.T., Brassell, S.C. and Eglinton, G., 1978. Organic geochemical indicators of palaeoenvironmental conditions of sedimentation. Nature, 272:216-222.

Espitalié, J., Deroo, G., and Marquis, F., 1985. La pyrolyse Rock-Eval et ses applications. Rev. Inst. Fr. Pet., 40/5:563-579; 40/6:755-784.

Espitalié, J., Laporte, J.L., Leplat, P., Madec, M., Marquis, F., Paulet, J., and Boutefeu, A., 1977. Méthode rapide de caractérisation des roches mères, de leur potentiel pétrolier et de leur degré d'évolution. Rev. Inst. Fr. Pet., 32:23-42.

Fowler, M.G., and Brooks, P.W., 1990. Organic geochemistry as an aid in the interpretation of the history of oil migration into different reservoirs at the Hibernia K-18 and Ben Nevis I-45 wells, Jeanne d'Arc Basin, offshore eastern Canada. Org. Geochem., 16:461-475.

Gatliff, R.W., 1990. The Petroleum Prospects of the Kingdom of Tonga. South Pacific Appl. Geosci. Comm., Suva.

Grantham, P.J., and Wakefield, L.L., 1988. Variations in the sterane carbon number distributions of marine source rocks derived oils through time. Org. Geochem., 12:61-73.

Hunt, J.M., 1979. Petroleum Geochemistry and Geology: San Francisco (W.H Freeman)

Jiang, Z., Fowler, M.G., Lewis, C.A., and Philp, R.P., 1990. Polycyclic alkanes in a biodegraded oil from the Kelamayi oilfield, northwestern China. Org. Geochem., 15:35-46.

\footnotetext{
Abbreviations for names of organizations and publication titles in ODP reference lists follow the style given in Chemical Abstracts Service Source Index (published by American Chemical Society).
} 
Katz, B.J., 1983. Limitations of "Rock-Eval" pyrolysis for typing organic matter. Org. Geochem., 4:195-199.

Mackenzie, A.S., 1984. Application of biological markers in petroleum geochemistry. In Brooks, J., and Welte, D. (Eds.), Advances in Petroleum Geochemistry (Vol. 1): London (Academic Press), II5-214.

Maung, T.U., Anscombe, K.J., and Tongilava, S.L., 1981. Assessment of Petroleum Potential of the Southern and Northern Parts of the Tonga Platform. Tech. Rep.-U. N. Econ. Soc. Comm. Asia Pac., CCOP/SOPAC, 18.

McKirdy, D.M., Aldridge, A.K., and Ypma, P.J.M., 1983. A geochemical comparison of some oils from Pre-Ordovician carbonate rocks. In Bjorøy, M., et al. (Eds.), Advances in Organic Geochemistry 1981: Chichester (Wiley), 99-107.

Moldowan, J.M., Fago, F.J., Huizinga, B.J., and Jacobson, S.R., 1991. Analysis of oleanane and its occurrence in Upper Cretaceous rocks. In Manning, D.A.C. (Ed.), Organic Geochemistrv. Advances and Applications in Energy and the Natural Environment (15th Meeting of European Association of Organic Geochemists Poster Abstracts): Manchester (Manchester Univ. Press), 195-197.

Moldowan, J.M., Fago, F.J., Lee, C.Y., Jacobson S.R., Watt. D.S., Slougui, N.-E., Jeganathan, A., and Young, D.C., 1990. Sedimentary 24-n-propylcholestanes, molecular fossils diagnostic of marine algae. Science, 247:309-312.

Parson, L., Hawkins, J., Allan, J., et al., 1992. Proc. ODP, Init. Repts., 135: College Station, TX (Ocean Drilling Program).

Sandstrom, M.W.. 1985. Organic chemistry of dredge samples and oil seeps from the southern Tonga platform. In Scholl, D.W., and Vallier, T.L. (Eds.),
Geology and Offshore Resources of Pacific Island Arcs-Tonga Region. Circum-Pac. Counc. Energy Miner. Resour., Earth Sci. Ser., 2:129-129.

Sandstrom, M.W., and Philp. R.P., 1984. Biological marker analysis and stable carbon isotopic composition of oil seeps from Tonga. Chem. Geol., 43:167-180.

Snowdon, L.R., and Meyers, P.A.. 1992. Source and maturity of organic matter in sediments and rocks from Sites 759, 760, 761, and 764 (Wombat Plateau) and Sites 762 and 763 (Exmouth Plateau). In von Rad, U., Haq. B.U., et al., Proc. ODP, Sci. Results, 122: College Station, TX (Ocean Drilling Program), 309-315.

Summons, R.E., Volkman, J.K., and Boreham, C.J., 1987. Dinosterane and other steroidal hydrocarbons of dinoflagellate origin in sediments and petroleum. Geochim. Cosmochim. Acta, 51:3075-3082.

ten Haven, H.L., and Rullkötter, J., 1988. The diagenetic fate of taraxer-14-ene and oleanene isomers. Geochim. Cosmochim. Acta. 52:2543-2548.

Tissot, B.P., and Welte. D.H., 1984. Petroleum Formation and Occurrence (2nd ed.): Heidelberg (Springer-Verlag).

Volkman, J.K., Alexander, R., Kagi, R.I., and Rullkötter, J., 1983. Demethylated hopanes in crude oils and their applications in petroleum geochemistry. Geochim. Cosmochim. Acta, 47:785-794.

Date of initial receipt: 15 June 1992

Date of acceptance: 30 October 1992

Ms 135SR-125 